\title{
The link between organic aerosol mass loading and degree of oxygenation: an $\alpha$-pinene photooxidation study
}

\author{
L. Pfaffenberger ${ }^{1}$, P. Barmet ${ }^{1}$, J. G. Slowik ${ }^{1}$, A. P. Praplan ${ }^{1, *}$, J. Dommen ${ }^{1}$, A. S. H. Prévôt ${ }^{1}$, and U. Baltensperger ${ }^{1}$ \\ ${ }^{1}$ Laboratory of Atmospheric Chemistry, Paul Scherrer Institute, 5232 Villigen, Switzerland \\ *now at: Department of Physics, University of Helsinki, Helsinki, Finland
}

Correspondence to: A. S. H. Prévôt (andre.prevot@psi.ch)

Received: 23 July 2012 - Published in Atmos. Chem. Phys. Discuss.: 20 September 2012

Revised: 17 May 2013 - Accepted: 27 May 2013 - Published: 8 July 2013

\begin{abstract}
A series of smog chamber (SC) experiments was conducted to identify factors responsible for the discrepancy between ambient and SC aerosol degree of oxygenation. An Aerodyne high-resolution time-of-flight aerosol mass spectrometer is used to compare mass spectra from $\alpha$-pinene photooxidation with ambient aerosol. Composition is compared in terms of the fraction of particulate $\mathrm{CO}_{2}^{+}$, a surrogate for carboxylic acids, vs. the fraction of $\mathrm{C}_{2} \mathrm{H}_{3} \mathrm{O}^{+}$, a surrogate for aldehydes, alcohols and ketones, as well as in the Van Krevelen space, where the evolution of the atomic hydrogento-carbon ratio $(\mathrm{H}: \mathrm{C})$ vs. the atomic oxygen-to-carbon ratio $(\mathrm{O}: \mathrm{C})$ is investigated. Low (near-ambient) organic mass concentrations were found to be necessary to obtain oxygenation levels similar to those of low-volatility oxygenated organic aerosol (LV-OOA) commonly identified in ambient measurements. The effects of organic mass loading and $\mathrm{OH}$ (hydroxyl radical) exposure were decoupled by inter-experiment comparisons at the same integrated $\mathrm{OH}$ concentration. $\mathrm{An} \mathrm{OH}$ exposure between 3 and $25 \times 10^{7} \mathrm{~cm}^{-3} \mathrm{~h}$ is needed to increase $\mathrm{O}: \mathrm{C}$ by 0.05 during aerosol aging. For the first time, LVOOA-like aerosol from the abundant biogenic precursor $\alpha$ pinene was produced in a smog chamber by oxidation at typical atmospheric $\mathrm{OH}$ concentrations. Significant correlation between measured secondary organic aerosol (SOA) and reference LV-OOA mass spectra is shown by Pearson's $R^{2}$ values larger than 0.90 for experiments with low organic mass concentrations between 1.2 and $18 \mu \mathrm{g} \mathrm{m}^{-3}$ at an $\mathrm{OH}$ exposure of $4 \times 10^{7} \mathrm{~cm}^{-3} \mathrm{~h}$, corresponding to about two days of oxidation time in the atmosphere, based on a global mean $\mathrm{OH}$ concentration of $\sim 1 \times 10^{6} \mathrm{~cm}^{-3}$. $\alpha$-Pinene SOA is more oxygenated at low organic mass loadings. Because the degree of oxygenation influences the chemical, volatility and hygro-
\end{abstract}

scopic properties of ambient aerosol, smog chamber studies must be performed at near-ambient concentrations to accurately simulate ambient aerosol properties.

\section{Introduction}

Organic aerosol (OA) represents 20 to $90 \%$ of the submicron atmospheric aerosol (Jimenez et al., 2009 and references therein) and has numerous sources. It can be introduced directly by combustion and mechanical processes into the atmosphere as primary organic aerosol (POA) or can be formed by condensation of gas-phase reaction products with low vapor pressures resulting in secondary organic aerosol (SOA). Modeling of SOA formation and aging processes requires accurate prediction of both SOA mass concentration and composition. While traditional models underestimated the SOA burden (Volkamer et al., 2006) prediction of SOA mass has recently been improved through the use of the volatility basis set framework (Donahue et al., 2006; Robinson et al., 2007) although the system remains significantly underdetermined (Hodzic et al., 2010). In contrast, efforts to reproduce ambient SOA oxygenation levels using atmospherically relevant $\mathrm{OH}$ concentrations have been largely unsuccessful. Here we explore the factors governing the degree of oxygenation of $\alpha$ pinene SOA produced via photooxidation in smog chamber experiments.

Analysis of aerosol mass spectrometer (AMS) data using the positive matrix factorization (PMF) source apportionment method allows the total OA to be represented as a linear combination of factors representing various sources and/or processes. The SOA fraction is often represented in 
terms of semi-volatile oxygenated OA (SV-OOA) and lowvolatility oxygenated OA (LV-OOA) (Ulbrich et al., 2009; Jimenez et al., 2009). In addition to their volatility difference, SV-OOA has a lower atomic oxygen-to-carbon $(\mathrm{O}: \mathrm{C})$ ratio $(\sim 0.25-0.6)$ than $\mathrm{LV}-\mathrm{OOA}$ and often represents fresh aerosol closer to the source, while LV-OOA, with a higher $\mathrm{O}: \mathrm{C}$ ratio $(\sim 0.6-1.0)$ represents more aged $\mathrm{OA}(\mathrm{Ng}$ et al., 2010; DeCarlo et al., 2010; Lanz et al., 2010; Jimenez et al., 2009).

Two AMS mass fragments previously shown to be useful in describing atmospheric SOA occur at $m / z 44$ (mostly particulate $\mathrm{CO}_{2}^{+}$, with a minor contribution of $\mathrm{C}_{2} \mathrm{H}_{4} \mathrm{O}^{+}$) and $m / z 43$ (mostly $\mathrm{C}_{2} \mathrm{H}_{3} \mathrm{O}^{+}$for $\mathrm{SOA}$, with a lesser contribution from $\mathrm{C}_{3} \mathrm{H}_{7}^{+}$). The $f_{44}$ value, being the ratio of the organic fraction of $m / z \quad 44$ to total organics, has been empirically related to the atomic $\mathrm{O}: \mathrm{C}$ ratio for ambient measurements and is in large part derived from carboxylic acids, of which a larger fraction is found in more aged aerosols (Aiken et al., 2008; Duplissy et al., 2011). The ratio of organic $m / z 43$ to total organics $\left(f_{43}\right)$ is more closely related to fragmentation of aldehydes, ketones and alcohols. The organic mass fractions in unit mass resolution $f_{44}$ and $f_{43}$ are approximations for those in high resolution, being the organic mass fractions of particulate $\mathrm{CO}_{2}^{+}\left(f p \mathrm{CO}_{2}^{+}\right)$and of $\mathrm{C}_{2} \mathrm{H}_{3} \mathrm{O}^{+}\left(f \mathrm{C}_{2} \mathrm{H}_{3} \mathrm{O}^{+}\right)$. The $f_{44}$ and $f_{43}$ values observed in ambient LV-OOA and SV-OOA factors obtained by PMF analysis of 43 ambient datasets (Ng et al., 2010) typically fall within a triangular space. LV-OOA has high $f_{44}$ and low $f_{43}$, while SV-OOA has lower $f_{44}$ and a range of $f_{43}$ values. The same triangle has been transferred to high-resolution data within the Van Krevelen space (H:C vs. O:C) (Van Krevelen, 1950; $\mathrm{Ng}$ et al., 2011a; Heald et al., 2010). SOA produced in smog chamber (SC) studies typically falls within the range of ambient SV-OOA, almost always showing lower degrees of oxygenation than ambient LV-OOA ( $\mathrm{Ng}$ et al., 2010), with only a few exceptions (Bahreini et al., 2005; Chhabra et al., 2011). These mass spectral differences suggest that SC SOA evaporates at lower temperatures than ambient LV-OOA. Although volatility is not directly measured in most studies, Huffman et al. (2009) showed that SC SOA is typically more volatile than ambient SOA. SOA from various non-biogenic pure precursors can reach high degrees of oxygenation, although having higher or lower $f_{43}$ values than ambient. In an $\alpha$-pinene oxidation flow reactor experiment $f_{44}$ values as high as 0.25 were reached; however, these required $\mathrm{OH}$ concentrations that were orders of magnitude higher than in smog chambers (Ng et al., 2010). Not only volatility but also hygroscopicity was related to the atomic O:C ratio (Duplissy et al., 2011, 2008). More oxygenated particles take up more water at a given relative humidity, suggesting increased cloud formation potential.

Measurements of dark $\alpha$-pinene ozonolysis in a continuous-flow chamber by Shilling et al. (2009) demonstrated that the aerosol chemical composition depends on the total organic mass concentration; however, the generated aerosol was less oxygenated than ambient LV-OOA. For non-wall-loss-corrected organic mass loadings between $>140 \mu \mathrm{g} \mathrm{m}^{-3}$ and $0.5 \mu \mathrm{g} \mathrm{m}^{-3}, \mathrm{O}: \mathrm{C}$ values increasing from 0.29 to 0.45 and $\mathrm{H}: \mathrm{C}$ values decreasing from 1.51 to 1.38 were reported. Recently, LV-OOA-like aerosol was obtained in a smog chamber, but mostly by starting with oxygenated gas-phase precursors (Chhabra et al., 2011), whereas most primary volatile organic compound emissions are thought to be more hydrocarbon-like. However, these results indicate that the location of SOA in the $f p \mathrm{CO}_{2}^{+}-f \mathrm{C}_{2} \mathrm{H}_{3} \mathrm{O}^{+}$as well as in the Van Krevelen space is affected by precursor identity. Chhabra et al. (2011) showed O:C ratios for $\alpha$-pinene photooxidation of approximately $0.3-0.4$ for organic mass concentrations of $54-64 \mu \mathrm{g} \mathrm{m}^{-3}$ and $\mathrm{OH}$ exposures of $1.7-3.3 \times 10^{7} \mathrm{~cm}^{-3} \mathrm{~h}$.

Three recent studies performed in flow reactors found SOA from $\alpha$-pinene photooxidation falling to the range of LV-OOA (Lambe et al., 2011; Massoli et al., 2010; Kang et al., 2011). When high $\mathrm{OH}$ concentrations (e.g., $2 \times 10^{9}$ to $2 \times 10^{10} \mathrm{~cm}^{-3}$ in Lambe et al., 2011) are produced in flow reactors, the probability that a low-volatility reaction product collides with an $\mathrm{OH}$ radical and reacts further before it collides with a particle and condenses as SOA is enhanced. Thus, the accelerated chemistry may lead to a different set of products, while inhibiting slower condensed-phase reactions. Therefore the importance of heterogeneous reactions may also be enhanced; Slowik et al. (2012) found that heterogeneous reactions at $\mathrm{OH}$ exposures of $3 \times 10^{8} \mathrm{~cm}^{-3} \mathrm{~h}$ are sufficient to transform ambient biogenic aerosol to an LVOOA-like composition.

The inability of smog chambers to generate $\alpha$-pinene SOA with oxygenation, volatility and (potentially) hygroscopicity similar to ambient LV-OOA could be an important gap in the current understanding of ambient SOA. In this paper, results from an experimental study using $\alpha$-pinene, being, among other biogenic organic gases, an atmospherically relevant precursor for SOA, are presented. The high non-fossil SOA fraction together with a high contribution of monoterpenes to SOA in Marseille in summer time indicates that biogenic VOC are important SOA precursors (El Haddad et al., 2012). The aim of this study is to find the main driving factors responsible for the inability of smog chamber studies to yield LV-OOA-like aerosol from the biogenic precursor $\alpha$-pinene, even after the equivalent of tens of hours of atmospheric aging. $\mathrm{OH}$ exposures of $3-14 \times 10^{7} \mathrm{~cm}^{-3} \mathrm{~h}$ were reached, which is higher compared to the studies of $\mathrm{Ng}$ et al. (2011a) and Chhabra et al. (2011), but less than in typical flow reactor studies. 
Table 1. Overview of experiment conditions. Org max (wlc) is the wall-loss-corrected organic mass concentration at the end of the experiment. Radiation sources are UV or xenon (Xe) lights. The $\mathrm{OH}$ tracer butanol-d9 is abbreviated with but-d9. Black carbon (BC) and $\mathrm{NH}_{4} \mathrm{HSO}_{4}$ represent seed aerosol in experiment 7.

\begin{tabular}{|c|c|c|c|c|c|c|c|c|c|c|}
\hline $\begin{array}{c}\text { Expt. } \\
\text { no. }\end{array}$ & $\begin{array}{c}\text { Initial } \\
\alpha \text {-pinene } \\
{[\mathrm{ppb}]}\end{array}$ & $\begin{array}{c}\text { Org max } \\
\quad(\mathrm{wlc}) \\
{\left[\mu \mathrm{g} \mathrm{m}^{-3}\right]}\end{array}$ & $\begin{array}{c}\mathrm{RH} \\
\mathrm{av}(\mathrm{sd}) \\
{[\%]}\end{array}$ & $\begin{array}{c}\text { NO } \\
\text { av(sd) } \\
{[\mathrm{ppb}]}\end{array}$ & $\begin{array}{c}\mathrm{NO}_{2} \\
\mathrm{av}(\mathrm{sd})^{*} \\
{[\mathrm{ppb}]}\end{array}$ & $\begin{array}{l}\text { Radiation } \\
\text { source(s) }\end{array}$ & \multicolumn{4}{|c|}{ Added } \\
\hline 1 & 7 & 4.5 & $50(1)$ & $3.9(0.6)$ & $4.9(1.8)$ & $\mathrm{UV}+\mathrm{Xe}$ & HONO & & & \\
\hline 2 & 14 & 17.9 & $48(2)$ & $3.0(0.4)$ & $5.9(0.9)$ & $\mathrm{UV}+\mathrm{Xe}$ & HONO & & & \\
\hline 3 & 20 & 6.2 & $40(2)$ & $0.3(0.1)$ & $0.8(0.3)$ & $\mathrm{UV}+\mathrm{Xe}$ & HONO & but-d9 & $\mathrm{SO}_{2}$ & \\
\hline 4 & 22 & 1.8 & $44(1)$ & $4.2(0.9)$ & $20.0(9.9)$ & $\mathrm{UV}+\mathrm{Xe}$ & HONO & but-d9 & $\mathrm{SO}_{2}$ & NO \\
\hline 5 & 23 & 9.2 & $47(2)$ & $0.6(0.9)$ & $6.9(0.3)^{*}$ & $\mathrm{UV}+\mathrm{Xe}$ & & but-d9 & & $\mathrm{NO}_{2}$ \\
\hline 6 & 44 & 42.1 & $44(2)$ & $0.3(0.8)$ & $19.0(0.4)^{*}$ & $\mathrm{Xe}$ & & but-d9 & $\mathrm{O}_{3}$ & $\mathrm{NO}_{2}$ \\
\hline 7 & 45 & 97.2 & $28(2)$ & $1.0(0.2)$ & $3.6(1.3)$ & $\mathrm{UV}+\mathrm{Xe}$ & HONO & $\mathrm{BC}$ a & $\mathrm{NH}_{4} \mathrm{I}$ & $\mathrm{SO}_{4}$ \\
\hline 8 & 46 & 78.3 & $49(1)$ & $2.0(1.1)$ & $22.0(12.0)$ & $\mathrm{Xe}$ & HONO & & & \\
\hline 9 & 50 & 66.2 & $47(3)$ & $1.8(0.3)$ & $9.0(3.0)$ & $\mathrm{UV}+\mathrm{Xe}$ & HONO & & & \\
\hline
\end{tabular}

${ }^{*}$ Initial $\mathrm{NO}_{2}$ addition that decayed to zero during experiments 5 and 6.

\section{Method}

\subsection{Experimental setup}

Nine experiments (see Table 1) were carried out in the smog chamber (SC) of the Paul Scherrer Institute (PSI): a $27 \mathrm{~m}^{3}$ Teflon bag suspended in a temperature-controlled wooden housing. Four xenon arc lamps $\left(4 \mathrm{~kW}\right.$ rated power, $1.55 \times 10^{5}$ lumens each, XBO $4000 \mathrm{~W} / \mathrm{HS}$, OSRAM) were used to simulate the solar light spectrum. In addition, in seven of the nine experiments $80 \mathrm{UV}$ lights (Philips, Cleo performance $100 \mathrm{~W}$ ) located underneath the SC bag were illuminated to accelerate the aging process. The smog chamber housing is covered inside with a reflective aluminum foil to maintain light intensity and light diffusion. A comprehensive description of the PSI smog chamber is available in Paulsen et al. (2005).

During all experiments, photooxidation of the biogenic precursor $\alpha$-pinene led to secondary aerosol formation and growth. In general, experimental conditions were adjusted using the following sequence: humidification of the chamber, addition of seed aerosol if applicable, introduction of SOA precursor, addition of $\mathrm{OH}$ precursor, addition of $\mathrm{NO}_{\mathrm{x}}$ if applicable, mixing period, turning-on of xenon and/or UV lights to generate $\mathrm{OH}$ radicals followed by a reaction time of 5 to $22 \mathrm{~h}$. The procedure for each individual experiment is described in Sect. 2.2.1 and summarized in Table 1.

\subsubsection{Introduction of particle and gas-phase reactants into the chamber}

Liquid-phase $\alpha$-pinene (98\%, Aldrich) and optionally the hydroxyl radical $(\mathrm{OH})$ tracer (9-fold deuterated butanol, $98 \%$, D9, Cambridge Isotope Laboratories), hereafter referred to as butanol-d9, were sequentially injected with a syringe into an evaporation glass bulb heated to $80^{\circ} \mathrm{C}$. The two gas-phase compounds were carried with dilution and flush flows into the bag (each $15 \mathrm{~L} \mathrm{~min}^{-1}$, maintained for $15 \mathrm{~min}$ ) from an air purifier (737-250 series, AADCO Instruments, Inc., USA), further referred to as "pure air". The experiments were carried out at $40-50 \%$ relative humidity (RH), except experiment 6 , where the prevailing $\mathrm{RH}$ was $28 \pm 2 \%$. The temperature $(T)$ varied within a range of 21 to $24^{\circ} \mathrm{C}$ between experiments. Three $\mathrm{NO}_{\mathrm{x}}$ sources (HONO, NO and $\mathrm{NO}_{2}$ ) were added either in combination or separately during the different experiments. Table 1 provides an overview of the initial $\alpha$-pinene concentrations, maximum wall-losscorrected (wlc) organic mass concentrations, $\mathrm{RH}$, initial $\mathrm{NO}_{2}$ concentration before lights were switched on, average NO and $\mathrm{NO}_{2}$ concentrations during the experiments, the radiation source(s) and the seed added.

$\mathrm{HONO}$ was used as a source of both $\mathrm{NO}$ and $\mathrm{OH}$, except for experiments 5 and 6 . It was produced by continuous mixing of sodium nitrite $\left(\mathrm{NaNO}_{2}, 1-3 \mathrm{mmol} \mathrm{L}^{-1}\right)$ and sulfuric acid $\left(\mathrm{H}_{2} \mathrm{SO}_{4}, 10 \mathrm{mmol} \mathrm{L}^{-1}\right)$ solutions in a reaction vessel by means of a peristaltic pump (Taira and Kanda, 1990). The HONO product was entrained in $2.3-2.7 \mathrm{~L} \mathrm{~min}^{-1}$ pure air depending on the experiment. Before lights on, $1-5 \mathrm{ppbv}$ $( \pm 10 \%)$ of $\mathrm{HONO}$ was injected to provide $\mathrm{NO}_{\mathrm{x}}$ and enable photochemistry immediately after lights on (Initial concentrations: see Supplement Table S1). The injection continued throughout the experiments to maintain a similar NO concentration level.

In experiments 5 and $6, \mathrm{NO}_{2}$ served as the $\mathrm{NO}_{\mathrm{x}}$ source, with $6.9 \pm 0.7 \mathrm{ppbv}$ and $19.0 \pm 1.9 \mathrm{ppbv} \mathrm{NO}_{2}$ (purity: $98 \%$; 1005 ppmv $\pm 3 \%$ ), respectively, injected before lights on. During experiment 4 , NO $(99.8 \% ; 1005 \mathrm{ppmv} \pm 2 \%)$ was continuously injected in addition to HONO, and the flow was decreased stepwise from 10.0 to $3.8 \mathrm{~mL} \mathrm{~min}^{-1}$ (0.37 to $0.14 \mathrm{ppbv} \mathrm{min}^{-1}$ ), which resulted in a slower increase of $\mathrm{NO}_{2}$ and a constant level of $\mathrm{NO}$ in the chamber.

Before switching on the lights during experiment 7 , a suspension of $50 \mu \mathrm{LL}^{-1}$ black carbon (printer ink, Tokai carbon, Japan) containing black carbon and a solution of $4 \mathrm{~g} \mathrm{~L}^{-1}$ 
ammonium hydrogen sulfate $\left(\mathrm{NH}_{4} \mathrm{HSO}_{4}\right)$, both in water, were sequentially nebulized and introduced into the chamber with $0.6 \mathrm{~L} \mathrm{~min}^{-1}$ and a dilution flow of $10 \mathrm{~L} \mathrm{~min}^{-1}$ to act as seed particles. During experiments 3 and 4, $50 \mathrm{pptv}$ $\mathrm{SO}_{2}(99.98 \% ; 502 \mathrm{ppmv} \pm 2 \%)$ was injected to photochemically produce $\mathrm{H}_{2} \mathrm{SO}_{4}$ nucleation, providing an aerosol surface rapidly and thus accelerating SOA formation (Metzger et al., 2010). In experiment 6, eight hours after lights on, $123 \pm 4 \mathrm{ppbv}$ of $\mathrm{O}_{3}$ were added to the existing concentration of $41 \pm 1 \mathrm{ppbv}$ to investigate whether this would accelerate oxidation compared to the earlier period of the experiment. To minimize SOA formation by $\alpha$-pinene ozonolysis, the injection was performed only after $99 \%$ of the $\alpha$-pinene had reacted.

Once all initial gas- and aerosol-phase components were present in the bag, a 20 to 30 min mixing period was allowed before the lights were switched on. After each experiment the smog chamber was cleaned by the injection of several ppmv of ozone for $5 \mathrm{~h}$ and irradiation for $10 \mathrm{~h}$ with UV lights at $20^{\circ} \mathrm{C}$, followed by a flushing period with pure air and high relative humidity $(\sim 70 \%)$ at $30^{\circ} \mathrm{C}$ for at least $20 \mathrm{~h}$.

To ensure that the organic matter (OM) formed during the experiments is not significantly influenced by background contamination in the smog chamber, blank experiments before, during and after the campaign were carried out. The conditions of the five blank experiments are listed in Table S2 in the Supplement. During two blank experiments (B1 and $\mathrm{B} 2$ ) at $\mathrm{RH} \approx 50 \%$ with neither $\mathrm{HONO}$ nor seed aerosol present, the maximum mass concentration measured by the SMPS was $0.16 \mu \mathrm{g} \mathrm{m}^{-3}$ and $0.03 \mu \mathrm{g} \mathrm{m}^{-3}$ after $5 \mathrm{~h}$ and $8 \mathrm{~h}$ exposure to UV and xenon lights, respectively. A blank experiment (B3) with $6.6 \pm 0.2 \mu \mathrm{g} \mathrm{m}^{-3}$ ammonium sulfate $\left(\left(\mathrm{NH}_{4}\right)_{2} \mathrm{SO}_{4}\right)$ seed, $10 \mathrm{ppbv} \mathrm{HONO}$ and a relative humidity of $61 \pm 6 \%$ yielded a peak organic mass concentration of $1.7 \pm 0.1 \mu \mathrm{g} \mathrm{m}^{-3} 30 \mathrm{~min}$ after lights on. A second and third seeding period $1 \mathrm{~h}$ and $2 \mathrm{~h}$ after lights on resulted in a slight increase in the organic mass concentration. Two additional seeded blank experiments (B4 with $\mathrm{NO}$ and $\mathrm{B} 5$ with $\mathrm{HONO}$ ) with a lower $\left(\mathrm{NH}_{4}\right)_{2} \mathrm{SO}_{4}$ concentration yielded only $0.1-$ $0.16 \mu \mathrm{g} \mathrm{m}^{-3}$ organic mass concentration. The significantly higher background concentration in blank experiment $\mathrm{B} 3 \mathrm{can}$ be explained by the contamination of the $\left(\mathrm{NH}_{4}\right)_{2} \mathrm{SO}_{4}$ seed solution with organic compounds. There is evidence that primary organic aerosol $\left(\sim 0.3 \mu \mathrm{g} \mathrm{m}^{-3}\right)$ was injected with the seed. In addition, it is likely that water-soluble organic compounds are injected with the aqueous seed, which are then oxidized in the gas phase and form additional SOA. Moreover, the yield of secondary organic mass is enhanced by the surface provided by the seed. Condensation occurs earlier in the seeded blank experiments than for the unseeded blanks, where higher vapor pressures are required for nucleation. Experiment 7 (which is most similar to the seeded blank experiment) included a concentration of $69.2 \mu \mathrm{g} \mathrm{m}^{-3}$ and thus an organic mass concentration well above the blank value. The organic mass concentration of the unseeded experiments is well above that of the blank experiments B1, B2, B4 and B5.

In general, it is difficult to quantify the contribution of contaminants in the smog chamber to the total organic aerosol mass over the course of an experiment. We estimate the time evolution of contaminant mass using the multilinear engine (ME-2, Paatero, 1999), as implemented in Igor Pro (Wavemetrics, Inc.) by Canonaco et al. (2013). ME-2 represents the mass spectral time series recorded during the experiment as a linear combination of statistic factor mass spectra and their time-dependent intensities, while allowing some or all of the factor spectra to be constrained using a priori information. In this case, contaminant mass spectra were constrained ( $a$ value: 0 ) using one of the three selected spectra collected during the blank experiment B3, while two additional left free. One hundred twenty iterations (40 for each mass spectrum after the first, second and third seeding period, representing three different aging times and chemical compositions) of the model using different randomly distributed initial values resulted in a contribution of the constrained blank MS between 6.6 and $9.9 \%$ in the first two hours to between 10 and $20 \%$ in the last three hours of experiment 4 with the lowest organic mass concentration. A detailed description of the model runs and results can be found in the Supplement (Fig. S1).

Another indication that the low-concentration experiments are not dominated by the background contamination is shown in Fig. S2 of the Supplement. The chemical composition of SOA in blank experiment B3 measured by the AMS differs from that measured during the low concentration experiments of the study as shown by their different location in the Van Krevelen space ( $\mathrm{H}: \mathrm{C}$ vs. $\mathrm{O}: \mathrm{C})$. We conclude that only experiment 4 with the lowest organic mass concentration in this study is impacted by a non-negligible amount of contaminants from the smog chamber system.

\subsubsection{Instrumental setup}

Various instruments were used to monitor gas and aerosol properties in the PSI smog chamber. A high-resolution timeof-flight aerosol mass spectrometer (HR-ToF-AMS, Aerodyne Research, Inc., Billerica, MA, USA) was operated online to measure the chemical composition (organics, ammonium, nitrate, sulfate, chloride) of non-refractory submicron particles (DeCarlo et al., 2006). Because this instrument samples at a low flow rate $\left(0.1 \mathrm{~L} \mathrm{~min}^{-1}\right)$, a supporting flow of $\sim 3 \mathrm{~L} \mathrm{~min}^{-1}$ was maintained parallel to the AMS inlet to minimize diffusive losses in the sampling lines. Gasphase compounds with a higher proton affinity than water $\left(166.5 \mathrm{kcal} \mathrm{mol}^{-1}\right)$ were measured with a proton transfer reaction mass spectrometer (PTR-MS, Ionicon). Massto-charge ratios related to $\alpha$-pinene $(\mathrm{m} / z 81$ and $\mathrm{m} / z$ 137) and the $\mathrm{OH}$ tracer butanol-d $9(\mathrm{~m} / z, 66)$ were analyzed in detail (see Sect. 2.2). A chemiluminescence-based $\mathrm{NO}_{\mathrm{x}}$ instrument (Monitor Labs 9841A $\mathrm{NO}_{\mathrm{x}}$ analyzer) was attached 
to the HONO source to monitor the injected concentration throughout the experiment. A modified $\mathrm{NO}_{\mathrm{x}}$ instrument including a photolytic $\mathrm{NO}_{2}$-to-NO converter (Thermo Environmental Instruments $42 \mathrm{C}$ trace level $\mathrm{NO}_{\mathrm{x}}$ analyzer) and two ozone monitors (Monitor Labs 8810 ozone analyzer, Environics S300 ozone analyzer) monitored the gas phase in the chamber. A scanning mobility particle sizer (SMPS, consisting of a TSI condensation particle counter (CPC) 3022A and a TSI differential mobility analyzer (DMA) 3081) measured the aerosol size distribution and a condensation particle counter (TSI CPC 3025A) the total particle number concentration (diameter $d>3 \mathrm{~nm}$ ), respectively.

The unit mass and high-resolution data from the HRToF-AMS were corrected for contributions from the gas phase. The contributions of multiple species to the same integer $\mathrm{m} / \mathrm{z}$ were deconvolved using a fragmentation-tablebased approach (Allan et al., 2004; Aiken et al., 2008). The fragmentation tables were optimized for the current dataset, which required changes at $m / z 14,36,39,40,46,47,48$, $64,65,80,81$, and 98, as discussed in the Supplement (see Table S3).

The total organic mass concentration was derived using the chemical composition (organics, ammonium, nitrate, sulfate, chloride) measurements from the HR-ToF-AMS and the total volume measured with the SMPS. The ratio of SMPS to HR-ToF-AMS volume, after applying compound-specific densities, results in a correction factor applied to the measured HR-ToF-AMS organic mass concentration (details in the Supplement). The data were further corrected for wall losses, as described in Sect. 2.3.

\subsection{Estimation of $\mathrm{OH}$ exposure}

Depending on the design of smog chamber experiments, the $\mathrm{OH}$ concentration and thus the photochemical age of the reaction system can vary considerably between experiments. Furthermore, within a single experiment the photochemical age is not necessarily directly proportional to the light exposure time. Therefore we here discuss reaction time in terms of $\mathrm{OH}$ exposure (unit: $\mathrm{cm}^{-3} \mathrm{~h}$ ), defined as the $\mathrm{OH}$ concentration integrated over time. This scale is preferable when comparing the evolution of experiments, especially when observing oxidation processes, as it is the chemically relevant aging time. In this study we determine $\mathrm{OH}$ exposures combining two methods: an $\mathrm{OH}$ tracer method introduced by Barmet et al. (2012) and a method based on the initial decay of the gasphase precursor $\alpha$-pinene.

\subsubsection{OH tracer method}

Via a heated glass bulb, $1.5 \mu \mathrm{L}$ (corresponding to $\sim 14.5 \mathrm{ppbv}$ ) of the $\mathrm{OH}$ tracer butanol-d9 (detected as $\mathrm{M}+\mathrm{H}^{+}-\mathrm{H}_{2} \mathrm{O}$ at $m / z$ 66) was injected into the chamber (Sect. 2.1.1). The $\mathrm{OH}$ tracer was present during the last hour of experiment 5 , the second half of experiment 6 , and for the entire lengths of experiments 3 and 4. Butanol-d9 is consumed by reaction with $\mathrm{OH}$ and diluted by the HONO input described in Sect. 2.1.1 (we assume as a first approximation a constant chamber volume, $V$ ) following the reaction kinetics governed by Eq. (1):

$$
\begin{aligned}
& \frac{\mathrm{d}(\text { butanol-d9) }}{\mathrm{d} t}=-k_{\mathrm{OH}, \text { butanol-d9 }} \cdot[\mathrm{OH}] \cdot[\text { butanol-d9]- } \\
& \frac{f_{\mathrm{dil}}}{V} \cdot[\text { butanol-d9], }
\end{aligned}
$$

where $k_{\mathrm{OH} \text {,butanol-d } 9}=3.4 \times 10^{-12} \mathrm{~cm}^{3}$ molecules ${ }^{-1} \mathrm{~s}^{-1}, V$ represents the chamber volume $\left(27 \mathrm{~m}^{3}\right)$ and $f_{\text {dil }}$ the dilution flow $\left[\mathrm{m}^{3} \mathrm{~s}^{-1}\right]$.

$$
\begin{gathered}
\text { OH exposure }=-\int_{t_{1}=0}^{t}\left(\frac{1}{k_{\mathrm{OH}, \text { butanol-d } 9}}\right. \\
\left.\cdot\left(\frac{\Delta \ln (\text { butanol-d } 9)}{\Delta t}+\frac{f_{\mathrm{dil}}}{V}\right)\right) \mathrm{d} t .
\end{gathered}
$$

The slope of the temporal decay of $\ln ($ butanol-d9) at each time step was divided by the reaction rate constant

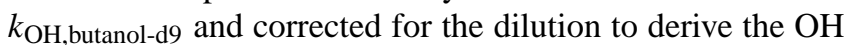
concentration at each time step. Integrating this term with time (Eq. 2) results in the $\mathrm{OH}$ exposure (Barmet et al., 2012).

\subsection{2 $\alpha$-pinene method}

Similar to the $\mathrm{OH}$ tracer decay, the decay of $\alpha$-pinene can be utilized to derive the $\mathrm{OH}$ concentration. Compared to the $\mathrm{OH}$ tracer method, limitations of this method are the more rapid consumption of $\alpha$-pinene and its simultaneous reaction with both $\mathrm{OH}$ and $\mathrm{O}_{3}$ as shown by Eq. (3). The $\mathrm{OH}$ exposure was therefore derived from the decay of $\ln (\alpha$-pinene), while correcting for the time-dependent reaction with $\mathrm{O}_{3}$ and, if present, for the dilution of the chamber air due to the HONO input (described in Sect. 2.2.1) as shown in Eq. (4).

$$
\begin{gathered}
\frac{\mathrm{d}(\alpha \text {-pinene })}{\mathrm{d} t}=-k_{\mathrm{OH}} \cdot[\mathrm{OH}] \cdot[\alpha \text {-pinene }]- \\
k_{\mathrm{O}_{3}} \cdot[\alpha \text {-pinene }]-\frac{f_{\mathrm{dil}}}{V} \cdot[\alpha \text {-pinene }],
\end{gathered}
$$

where $k_{\mathrm{OH}}=5.3 \times 10^{-11} \mathrm{~cm}^{3}$ molecules ${ }^{-1} \mathrm{~s}^{-1}$ and $k_{\mathrm{O}_{3}}=$ $8.9 \times 10^{-17} \mathrm{~cm}^{3}$ molecules ${ }^{-1} \mathrm{~s}^{-1}$,

$$
\begin{aligned}
& \mathrm{OH} \text { exposure }=-\int_{t_{1}=0}^{t}\left(\frac { 1 } { k _ { \mathrm { OH } } } \cdot \left(\frac{\Delta \ln (\alpha-\text { pinene })}{\Delta t}+\right.\right. \\
& \left.\left.k_{\mathrm{O}_{3}} \cdot\left[\mathrm{O}_{3}\right]+\frac{f_{\text {dil }}}{V}\right)\right) \mathrm{d} t .
\end{aligned}
$$

Only data fulfilling the criterion $\alpha$-pinene $\geq 1 \mathrm{ppbv}$ were used to ensure all measurements fell well above the PTRMS detection limit. After $\alpha$-pinene decayed below 1 ppbv, the $\mathrm{OH}$ concentration was assumed to be constant for the rest of the experiment time for experiments with continuous HONO addition. 


\subsubsection{Application of the methods to the dataset}

The two estimates of $\mathrm{OH}$ exposure were compared in experiments 3 and 4, where both $\alpha$-pinene and butanol-d9 were above detection limit throughout the experiment (Fig. S3, Supplement). The methods agree within $20 \%$ for later in the experiment, which shows that the $\alpha$-pinene method is valid at least for experiments with constant HONO input and thus a constant source of $\mathrm{OH}$ radicals.

The $\alpha$-pinene method was utilized to derive the $\mathrm{OH}$ concentration of experiments 7, 8 and 9 with constant HONO input and $\alpha$-pinene above detection limit for at least $1.3 \mathrm{~h}$. The $\mathrm{OH}$ exposure from a repeat experiment using the butanol-d9 method was applied to experiments 1 and 2 , conducted at substantially higher $\mathrm{HONO} / \alpha$-pinene ratios $(0.2$ and 0.4 , respectively). The fast decay of $\alpha$-pinene within the first $30 \mathrm{~min}$ during those two experiments due to the high accumulated HONO concentration before lights on and off-gassing from the walls after lights on, as previously measured by Metzger et al. (2008), gives rise to an overestimation of the $\mathrm{OH}$ exposure when using the $\alpha$-pinene method. This is due to the assumption of a constant $\mathrm{OH}$ concentration once the $\alpha$-pinene is consumed. The repeat experiment shows the same characteristics in the $\alpha$-pinene decay, with the advantage of having the $\mathrm{OH}$ tracer butanol-d9 present for the whole experiment. A comparison of the three experiments is shown in Fig. S4 of the Supplement. By applying the $\mathrm{OH}$ exposure of the repeat experiment to experiments 1 and 2, an overestimation of the $\mathrm{OH}$ concentration later in the experiment could be avoided.

In the course of experiments 5 and 6 , the initially added $\mathrm{NO}_{\mathrm{x}}$ concentration decayed to very low concentrations, causing a substantial change in the gas-phase chemistry including the production rate of ozone and thus $\mathrm{OH}$ and the fate of peroxy radicals. An indication of changes in chemistry is the change in the steepness of the ozone increase during the experiments 5 ( $1.5 \mathrm{~h}$ after lights on) and 6 (5.5 h after lights on), once the $\mathrm{NO}_{\mathrm{x}}$ decayed to low concentrations. One may assume that $\mathrm{RO}_{2}$ radicals react less with $\mathrm{NO}$ in this "low $\mathrm{NO}_{\mathrm{x}}$ " regime and more with $\mathrm{HO}_{2}$ and $\mathrm{RO}_{2}$ forming, e.g., peroxides. However there was no direct measure of $\mathrm{RO}_{2}$ or peroxides available.

In experiment 6 , the ozone leveled off before being increased artificially by the addition of $123 \pm 4 \mathrm{ppbv}$ of $\mathrm{O}_{3}$ eight hours after lights on. For those two experiments, $\mathrm{OH}$ exposures derived from the $\alpha$-pinene decay in the beginning and the decay of butanol-d9, added towards the end of the experiment, were merged. The mean $\mathrm{OH}$ concentration in the smog chamber was indirectly determined by dividing the $\mathrm{OH}$ exposure by the respective time period. The highest $\mathrm{OH}$ concentration was $5 \times 10^{7} \mathrm{~cm}^{-3}$ and occurred at the beginning of experiments 1 and 2. On average, the $\mathrm{OH}$ concentrations during the experiments were in the range of 0.12 $2.7 \times 10^{7} \mathrm{~cm}^{-3}$. A compilation of the derived $\mathrm{OH}$ exposures is shown in Fig. S5 in the Supplement. When comparing experiments utilizing the $\alpha$-pinene-derived $\mathrm{OH}$ exposure, note that the $\mathrm{OH}$ concentration is assumed to be constant after the drop below the threshold of $1 \mathrm{ppbv} \alpha$-pinene. This extrapolation leads to uncertainties of the $\alpha$-pinene derived $\mathrm{OH}$ exposure, which increases with experiment time. Nevertheless these uncertainties do not alter the main outcome of the study.

\subsection{Wall loss correction}

The measured aerosol mass concentration in the smog chamber is the net result of mass produced in the chamber and mass lost to the walls. Wall loss rates were determined from a period near the end of the experiment where chemical changes to the aerosol have slowed to the point that wall losses are expected to be the dominant factor controlling changes in the measured particle mass. The measured (AMS) aerosol mass during this period was fitted with an exponential. The data were then corrected by dividing the measured organic mass concentration by the exponential decay (see Fig. S6 in the Supplement). The estimated half-lives ranged between 2.8 and $10 \mathrm{~h}$, the maximum derived from experiment 8 , with a very short period to fit. Selecting a period when minor mass production is still possible leads to a lower limit for the wall loss correction assuming no major fragmentation due to the UV light exposure and no major loss of vapors to the walls. This may lead to some underestimation of the aerosol loading, which however is difficult to quantify.

\section{Results}

\subsection{General reproducibility of the aerosol degree of oxygenation}

The vaporization and ionization processes in the AMS fragment the sampled aerosol compounds. As described in the Introduction, the fraction of particulate $\mathrm{CO}_{2}^{+}\left(f p \mathrm{CO}_{2}^{+}\right)$and the corresponding organic mass fraction $f_{44}$ (defined as the organic signal at $\mathrm{m} / \mathrm{z} 44$ normalized to the total organic mass) are related to carboxylic acids and proportional to the atomic $\mathrm{O}: \mathrm{C}$ ratio, whereas the fraction of fragment $\mathrm{C}_{2} \mathrm{H}_{3} \mathrm{O}^{+}$ $\left(f \mathrm{C}_{2} \mathrm{H}_{3} \mathrm{O}^{+}\right)$and the corresponding organic mass fraction $f_{43}$ are related to aldehydes, ketones and alcohols. The higher the $\mathrm{O}: \mathrm{C}$, the more oxygenated the aerosol. The $f_{44-} f_{43}$ space was used to separate the two factors LV-OOA and SV-OOA (Ng et al., 2010) and is used here in Fig. 1a and b to describe the chemical evolution of aerosol derived from $\alpha$-pinene photooxidation in this study. Figure 1a shows 30-min averages of $f p \mathrm{CO}_{2}^{+}$vs. $f \mathrm{C}_{2} \mathrm{H}_{3} \mathrm{O}^{+}$from high-resolution data, while Fig. $1 \mathrm{~b}$ compares 30-min averaged data of this study with other studies (Chhabra et al., 2011; Kang et al., 2011; Lambe et al., 2011) in the $f_{44}-f_{43}$ space with each of the experiments marked by a different symbol. The legend in Fig. 1a gives the final organic mass concentration reached in each experiment after wall loss correction. Despite varying organic mass concentrations, $\mathrm{OH}$ concentrations, $\mathrm{NO}_{\mathrm{x}}$ concentrations and $\mathrm{RH}$ 

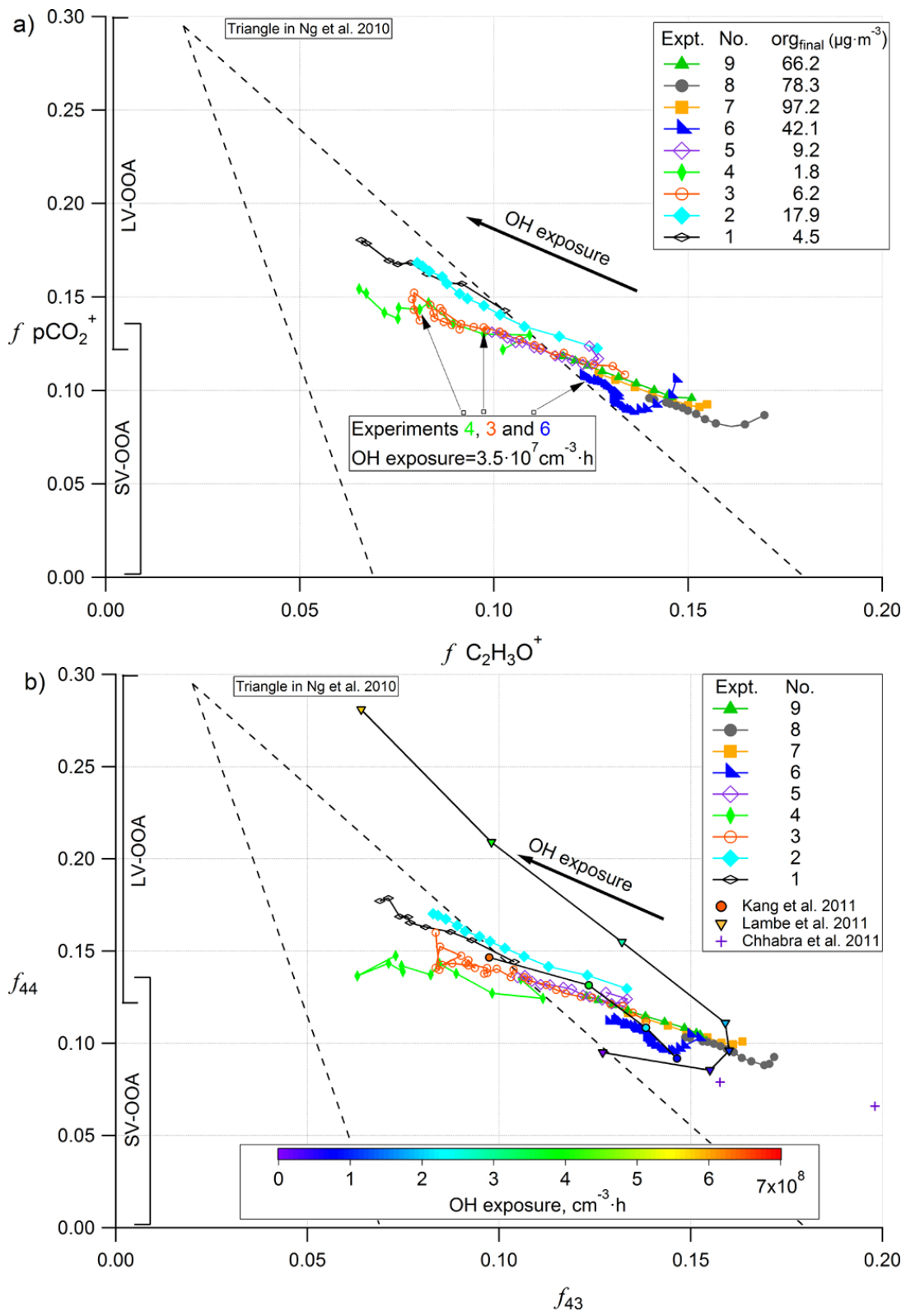

Fig. 1. (a) Thirty-minute averages (except expt. 4: $60 \mathrm{~min}$ ) of $f p \mathrm{CO}_{2}^{+}$vs. $f \mathrm{C}_{2} \mathrm{H}_{3} \mathrm{O}^{+}$color coded for the nine experiments. The legend shows the final wall-loss-corrected organic mass concentration at the end of each experiment. The three arrows indicate the $f p \mathrm{CO}_{2}^{+}-f \mathrm{C}_{2} \mathrm{H}_{3} \mathrm{O}^{+}$pair when an $\mathrm{OH}$ exposure of $3.5 \times 10^{7} \mathrm{~cm}^{-3} \mathrm{~h}$ is reached for selected experiments $(4,3,6)$. Dashed lines represent the observed range of ambient SOA (Ng et al., 2010). (b) Unit mass resolution organic mass fraction $f_{44}$ vs. $f_{43}$ color coded for the nine experiments. For comparison, environmental chamber (Chhabra et al., 2011) and flow reactor data (Kang et al., 2011; Lambe et al., 2011) of $\alpha$-pinene photooxidation experiments are shown and color coded by the $\mathrm{OH}$ exposure.

in the smog chamber (see Table 1), all experiments are located within the same region on the right-hand side of the triangle originating from ambient data (Ng et al., 2010). Experiment 6,7 and 8 show an initial decrease in $f p \mathrm{CO}_{2}^{+}$due to the condensation of early-generation semi-volatile organic compounds, as shown previously in Baltensperger et al. (2005). During the ongoing oxidation reactions in the smog chamber more highly oxygenated products are formed, resulting in an increased $f p \mathrm{CO}_{2}^{+}$together with a decreased $f \mathrm{C}_{2} \mathrm{H}_{3} \mathrm{O}^{+}$. This causes movement from the lower right to the upper left in Fig. 1a and $\mathrm{b}$ with increasing $\mathrm{OH}$ exposures, indicated by the arrows. Together with, e.g., SOA from wood burning, which is found on the left-hand side (Heringa et al., 2011), the mixture of aerosol from several sources can explain a wide range of the empirically derived triangle. The three arrows 
indicating $f p \mathrm{CO}_{2}^{+}-f \mathrm{C}_{2} \mathrm{H}_{3} \mathrm{O}^{+}$pairs at the same $\mathrm{OH}$ exposure are explained in Sect. 3.2.

Figure $1 \mathrm{~b}$ shows the organic mass fractions $f_{44}$ vs. $f_{43}$ in unit mass resolution for the nine experiments of this study compared to $\alpha$-pinene photooxidation studies in three other systems. Next to the color code by experiment number of this study, the data of Kang et al. (2011), Lambe et al. (2011) and Chhabra et al. (2011) are color coded with the $\mathrm{OH}$ exposure. Chhabra et al. (2011) measured in an environmental chamber (Caltech dual $28 \mathrm{~m}^{3}$ Teflon laboratory chambers), while Lambe et al. (2011) and Kang et al. (2011) utilized flow reactors (potential aerosol mass chamber, Kang et al., 2007) for their experiments. Chhabra et al. (2011) show slightly lower $f_{44}$ and higher $f_{43}$ at organic mass concentrations of

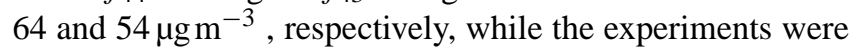
performed at much lower RH $(4.2 \%$; $4.9 \%)$ and with different $\mathrm{OH}$ precursors $\left(\mathrm{H}_{2} \mathrm{O}_{2} ; \mathrm{CH}_{3} \mathrm{ONO}\right)$ and $\mathrm{NO}_{\mathrm{x}}$ concentrations $(0 ; 800 \mathrm{ppbv})$ present. In the study of Kang et al. (2011) the organic mass concentrations $\left(90-110 \mu \mathrm{g} \mathrm{m}^{-3}\right)$ are similar to the high-concentration experiments in this study and for low $\mathrm{OH}$ exposures, and the location in the $f_{44}-f_{43}$ space is comparable. For higher $\mathrm{OH}$ exposures, the oxidation process continues on a similar slope as in this study, indicating further aging. Lambe et al. (2011) showed comparable pairs of $f_{44-} f_{43}$ for low $\mathrm{OH}$ exposures, while for higher $\mathrm{OH}$ exposures much higher $f_{44}$ was found, which the authors suggested to be due to the loss of mass after fragmentation in the particle takes place, seen by shrinking particles for higher OH exposures (Fig. S2, Lambe et al., 2011).

Thus, for the first time, an organic mass fraction $f_{44}$ as high as many ambient LV-OOA and well above the SV-OOA range is obtained from an $\alpha$-pinene photooxidation smog chamber study at ambient-like $\mathrm{OH}$ concentrations.

Figure 2 shows the Van Krevelen diagram ( $\mathrm{H}: \mathrm{C}$ vs. O : C) of the nine experiments (30-min averaged data, except expt. 4: $60 \mathrm{~min}$ average). The relationship between $f_{44}$ and $\mathrm{O}: \mathrm{C}$, as well as $f_{43}$ and $\mathrm{H}: \mathrm{C}$ is shown in Fig. S7a and $\mathrm{b}$ for data of this study. The diagram allows for interpretation of changes in functionality (slope -2 : aliphatic $\rightarrow$ carbonyl functionality; slope 0 : aliphatic $\rightarrow$ alcohol or peroxide functionality; slope -1 : addition of carboxylic acid functionality). Heald et al. (2010) found an average slope of -1 for bulk atmospheric and laboratory OA. The ongoing oxidation in the nine experiments results in an increased $\mathrm{O}: \mathrm{C}$ together with a decrease in $\mathrm{H}: \mathrm{C}$, seen in a movement from the upper left to the lower right in the figure. All experiments fall within the range of ambient data indicated by the dashed lines (Ng et al., 2011a) and follow a slope of roughly between -1 and -2 , indicated by the solid lines.

\subsection{Dependence of degree of oxygenation on the organic mass concentration}

Figure 1a shows three arrows pointing to $f p \mathrm{CO}_{2}^{+}-f \mathrm{C}_{2} \mathrm{H}_{3} \mathrm{O}^{+}$ pairs at the same $\mathrm{OH}$ exposure of $3.5 \times 10^{7} \mathrm{~cm}^{-3} \mathrm{~h}$ (aver- aged $\pm 15 \mathrm{~min}$ ), isolating the effect of organic mass concentration for three selected experiments (expt. no. 3, 4, 6) during which the $\mathrm{OH}$ tracer butanol-d9 was present in the chamber for most of the experiment. The respective $\mathrm{OH}$ exposures were derived according to the methods described in Sect. 2.2. The organic mass concentrations (wlc, averages and standard deviation for $\pm 15 \mathrm{~min}$, except expt. $4: 60 \mathrm{~min}$ ) at this $\mathrm{OH}$ exposure in experiments 6,3 and 4 were $42.3 \pm 0.6 \mu \mathrm{g} \mathrm{m}^{-3}$, $5.8 \pm 0.2 \mu \mathrm{g} \mathrm{m}^{-3}$ and $1.7 \pm 0.1 \mu \mathrm{g} \mathrm{m}^{-3}$, respectively. The corresponding averaged $f \mathrm{pCO}_{2}^{+}$values were $0.106 \pm 0.001$, $0.131 \pm 0.002$ and $0.140 \pm 0.014$, respectively. Seen by the differences in $f p \mathrm{CO}_{2}^{+}$for the three different mass loadings, the data clearly show that at the same $\mathrm{OH}$ exposure, the degree of oxygenation is dependent on the total organic mass concentration present in the chamber.

For a comprehensive comparison of all experiments described in this study, the $\mathrm{OH}$ exposure was utilized as the aging scale, rather than the time after lights on. The evolution of $\mathrm{O}: \mathrm{C}$ as a function of organic mass concentration (wlc), both averaged for $10 \mathrm{~min}$, is shown in Fig. 3 with each of the nine experiments marked by a different symbol and color-coded by the $\mathrm{OH}$ exposure. Initially, there is a period of rapid mass increase with a slow increase in $\mathrm{O}: \mathrm{C}$, followed by a later period of a continuous $\mathrm{O}: \mathrm{C}$ increase with only a slight further increase in mass. The precise rate and termination point of the late-experiment mass increase are somewhat uncertain due to corresponding uncertainties in the applied minimum wall loss correction method (Fig. S6, Supplement). The initial period is likely governed by condensation of early-generation, semi-volatile products and their condensation therefore yields a low increase in $\mathrm{O}: \mathrm{C}$. As aging proceeds, the gas-phase organics become more oxidized and thus more oxygenated (higher $\mathrm{O}: \mathrm{C}$ ) compounds condense. Additional aging of the particles is possible through repartitioning of semi-volatile condensed-phase OA to the gas phase, followed by gas-phase oxidation and recondensation of the oxygenated products. This process also increases $\mathrm{O}: \mathrm{C}$, while only slightly affecting the total OA mass. Therefore, partitioning is more strongly affected by the significantly varying mass concentrations between the nine experiments than the slight mass increase within a given experiment. Higher OA mass correspond to increased condensation of semi-volatile compounds, while low-volatility compounds occur in the particle phase even at low concentrations (Donahue et al., 2006). $\mathrm{Ng}$ et al. (2010) also suggest that more oxygenated compounds tend to be less volatile. The reaction of less oxygenated, semi-volatile compounds with $\mathrm{OH}$ proceeds in the gas phase until either (1) they become sufficiently oxygenated to condense (which requires a higher level of oxygenation than at high mass concentrations) or (2) they fragment sufficiently such that they will not enter the particle phase. Both pathways lead to an increase in the net $\mathrm{O}: \mathrm{C}$ for experiments conducted at low OA concentrations.

In Fig. 3 the color-coded squares correspond to average $\mathrm{O}: \mathrm{C}$ ratios and $\mathrm{OA}$ mass concentration (wlc) at $\mathrm{OH}$ 


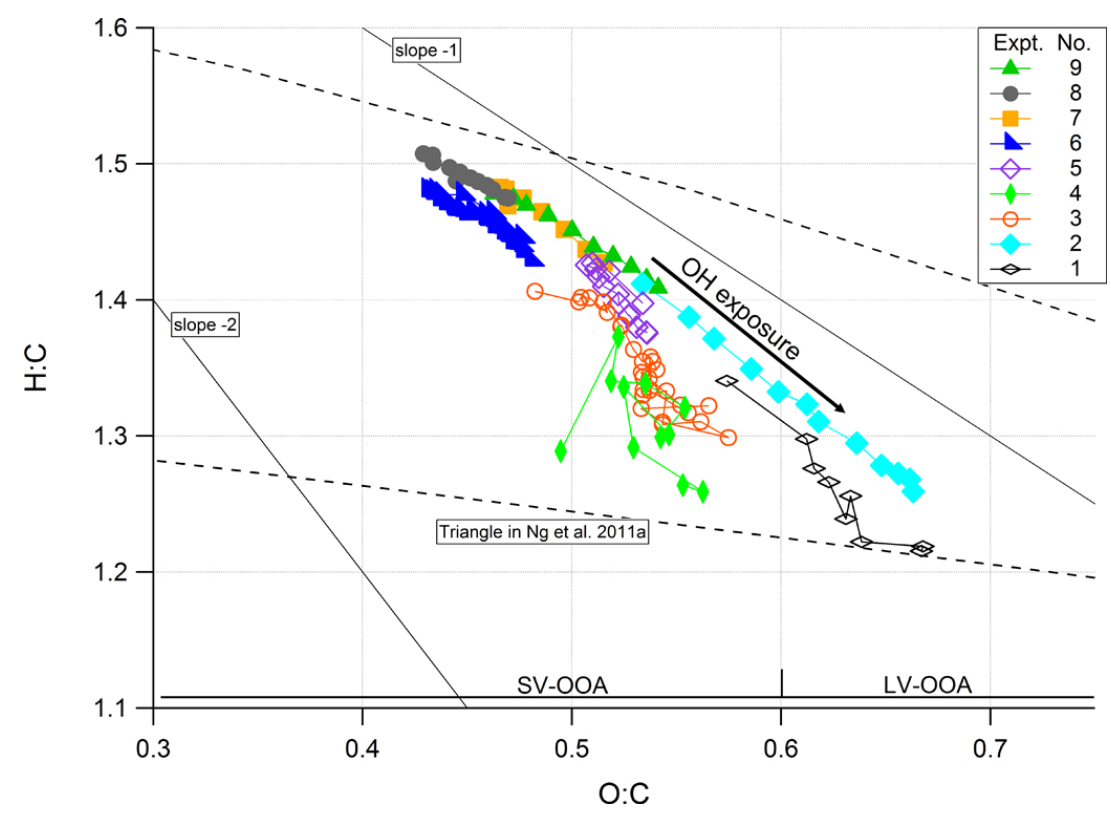

Fig. 2. Van Krevelen diagram (H: C vs. O : C ratio) of the nine experiments together with the observed range of ambient $\mathrm{SOA}$ represented by dashed lines. The data are averaged over $30 \mathrm{~min}$ (except expt. 4: $60 \mathrm{~min}$ ).

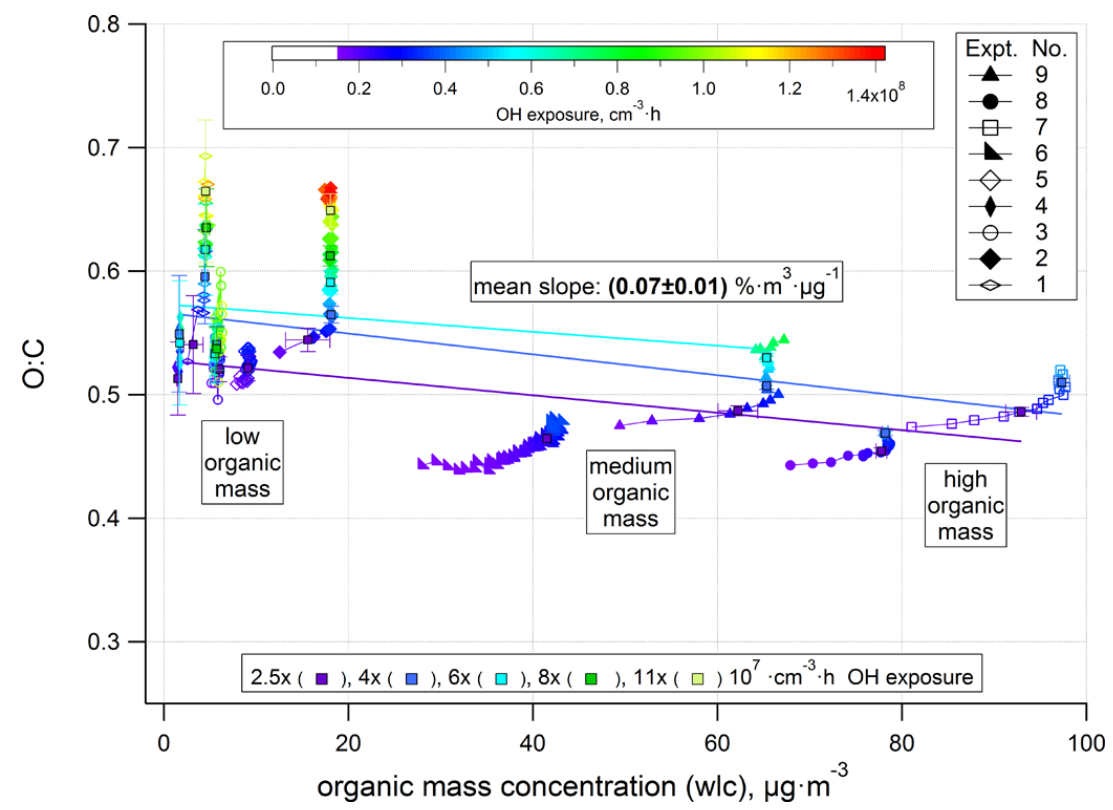

Fig. 3. $\mathrm{O}: \mathrm{C}$ ratio as a function of the organic mass concentration $\left(\mu \mathrm{g} \mathrm{m}^{-3}\right)$ in the chamber for the nine experiments. The color code indicates the $\mathrm{OH}$ exposure. Thirty-minute mean values at selected $\mathrm{OH}$ exposures are represented by colored squares (except expt. 4: 60-min average). The colored lines represent linear least orthogonal distance fits between $\mathrm{O}: \mathrm{C}$ and org (wlc) at three selected $\mathrm{OH}$ exposures with a mean slope of $(0.07 \pm 0.01) \% \mathrm{~m}^{3} \mu \mathrm{g}^{-1}$.

exposures of $2.5,4,6,8$ and $11 \times 10^{7} \mathrm{~cm}^{-3} \mathrm{~h}$. Averages were calculated as $\pm 15 \mathrm{~min}$ from the given $\mathrm{OH}$ exposure, except for expt. 4 , where a \pm 30 -min average was calculated. Linear (least orthogonal distance) fits of $\mathrm{O}: \mathrm{C}$ as a function of $\mathrm{OA}$ mass concentration at $2.5,4$ and $6 \times 10^{7} \mathrm{~cm}^{-3} \mathrm{~h} \mathrm{OH}$ exposure are shown by the lines in the corresponding color. Table 2 presents 30-min averages (except expt. 4: 60-min) of $\mathrm{O}: \mathrm{C}$ and organic mass concentration (wlc) for the five different $\mathrm{OH}$ exposures. The significant dependence of $\mathrm{O}: \mathrm{C}$ on the organic mass is shown by the slope $\Delta \mathrm{O}: \mathrm{C} / \Delta$ org (wlc), on average $(0.07 \pm 0.01) \% \mathrm{~m}^{3} \mu \mathrm{g}^{-1}$, with slopes and intercepts listed in Table 3. This implies that at typical atmospheric 
Table 2. Thirty-minute averages of $\mathrm{O}: \mathrm{C}$ and wall-loss-corrected organic mass concentration in $\mu_{\mathrm{g} \mathrm{m}}{ }^{-3}$, org (wlc) at the given $\mathrm{OH}$ exposures. The data are displayed in Fig. 3.

\begin{tabular}{|c|c|c|c|c|c|c|c|c|c|c|}
\hline \multirow[b]{3}{*}{ Expt. No. } & \multicolumn{10}{|c|}{$\mathrm{OH}$ exposure $\left[\times 10^{7} \mathrm{~cm}^{-3} \mathrm{~h}\right]$} \\
\hline & \multicolumn{2}{|r|}{2.5} & \multicolumn{2}{|r|}{4} & \multicolumn{2}{|r|}{6} & \multicolumn{2}{|r|}{8} & \multicolumn{2}{|r|}{11} \\
\hline & $\mathrm{O}: \mathrm{C}$ & Org (wlc) & $\mathrm{O}: \mathrm{C}$ & Org (wlc) & $\mathrm{O}: \mathrm{C}$ & Org (wlc) & $\mathrm{O}: \mathrm{C}$ & Org (wlc) & $\mathrm{O}: \mathrm{C}$ & Org (wlc) \\
\hline 1 & 0.54 & 3.2 & 0.60 & 4.4 & 0.62 & 4.5 & 0.64 & 4.6 & 0.66 & 4.5 \\
\hline 2 & 0.54 & 15.6 & 0.56 & 18.1 & 0.59 & 18.0 & 0.61 & 18.0 & 0.65 & 18.0 \\
\hline 3 & 0.52 & 6.0 & 0.54 & 5.7 & 0.53 & 5.5 & 0.54 & 5.7 & & \\
\hline $4^{*}$ & $0.51^{*}$ & $1.5^{*}$ & $0.55^{*}$ & $1.6^{*}$ & $0.54^{*}$ & $1.7^{*}$ & & & & \\
\hline 5 & 0.52 & 9.1 & & & & & & & & \\
\hline 6 & 0.46 & 41.5 & & & & & & & & \\
\hline 7 & 0.49 & 92.9 & 0.51 & 97.3 & & & & & & \\
\hline 8 & 0.45 & 77.8 & 0.47 & 78.2 & & & & & & \\
\hline 9 & 0.49 & 62.2 & 0.51 & 65.3 & 0.53 & 65.3 & & & & \\
\hline
\end{tabular}

* Data are 60-min averages.

Table 3. Slopes and intercepts of linear (least orthogonal distance) fits between $\mathrm{O}: \mathrm{C}$ and org (wlc). Fit lines are shown in Fig. 3 with the OH exposure as color code.

\begin{tabular}{|c|c|c|c|}
\hline \multirow[b]{2}{*}{$\mathrm{O}: \mathrm{C}=a+b \times$ org $($ wlc $)$} & \multicolumn{3}{|c|}{$\mathrm{OH}$ exposure $\left[\times 10^{7} \mathrm{~cm}^{-3} \mathrm{~h}\right]$} \\
\hline & 2.5 & 4 & 6 \\
\hline$a$ & $0.53 \pm 0.01$ & $0.57 \pm 0.01$ & $0.57 \pm 0.02$ \\
\hline$\left[\mathrm{m}^{3} \mu \mathrm{g}^{-1}\right]$ & $-0.00071 \pm 0.00022$ & $-0.00084 \pm 0.00027$ & $-0.00056 \pm 0.00079$ \\
\hline
\end{tabular}

concentration levels, partitioning effects on SOA oxygenation are highly sensitive to the organic mass concentration. Using typical atmospheric organic mass concentrations in smog chamber studies is not only crucial to reproduce the volatility and degree of oxygenation of ambient SOA but also to accurately determine cloud condensation nuclei activity due to the dependence of the hygroscopicity on the $\mathrm{O}: \mathrm{C}$ ratio (Duplissy et al., 2011). Ng et al. (2011b) found an even stronger dependence of $\mathrm{O}: \mathrm{C}$ on the organic mass concentration $\left(0.55 \% \mathrm{~m}^{3} \mu^{-1}\right)$ of ambient data with an unknown distribution of $\mathrm{OH}$ exposures (possibility of low $\mathrm{OH}$ exposure for high $\mathrm{OA}$ mass and high $\mathrm{OH}$ exposure for low $\mathrm{OA}$ mass).

\subsection{Dependence of degree of oxygenation on the $\mathrm{OH}$ exposure}

The degree of oxygenation reached by $\alpha$-pinene SOA depends on both the organic mass concentration (discussed above) and the $\mathrm{OH}$ exposure. For each experiment, the slope of $\Delta \mathrm{O}: \mathrm{C} / \Delta(\mathrm{OH}$ exposure) was fitted (least orthogonal distance fit) for the part of the experiment dominated by aging (rather than mass production), defined as the period after the peak of suspended organic mass concentration was reached in the chamber. The individual slopes are shown in Fig. S8 and summarized in Table S4 in the Supplement. An $\mathrm{OH}$ exposure between 3 and $25 \times 10^{7} \mathrm{~cm}^{-3} \mathrm{~h}$ is needed to increase $\mathrm{O}: \mathrm{C}$ by 0.05 . Table 4 shows $\mathrm{OH}$ exposures (and corresponding organic mass concentrations, wlc) required to obtain $\mathrm{O}: \mathrm{C}>0.6$, a typical lower limit value for LV-OOA. For experiments during which this threshold of 0.6 was not reached, the derived slopes of $\Delta \mathrm{O}: \mathrm{C} / \Delta(\mathrm{OH}$ exposure $)$ and intercepts were utilized to estimate the total $\mathrm{OH}$ exposure needed to do so. The $\mathrm{OH}$ exposure observed for oxidation of SOA to an $\mathrm{O}: \mathrm{C}$ value of $\sim 0.64$ in the Mexico City plume ( $\sim 4-5 \times 10^{7} \mathrm{~cm}^{-3} \mathrm{~h}, 6 \mathrm{~h}$ air transport time) as estimated from aircraft measurements (DeCarlo et al., 2010; Dusanter et al., 2009) is, despite different precursors, on the lower edge of the range of $\mathrm{OH}$ exposures required in this study.

\subsection{Classification of chemical composition using reference mass spectra}

To relate the aerosol chemical composition found in this study to ambient data, the SC organic mass spectra were compared to reference mass spectra retrieved from ambient measurements. These reference spectra were obtained from PMF analysis of a number of ambient datasets and compiled by $\mathrm{Ng}$ et al. (2011a) and are available on the AMS Spectral Database (Ulbrich et al., 2009). Figure 4 shows $R^{2}$ values (Pearson correlation) of the LV-OOA (filled circles) and SV-OOA (empty circles) unit mass spectra from $(\mathrm{Ng}$ et al., 2011a) with unit mass spectra from this study as a 


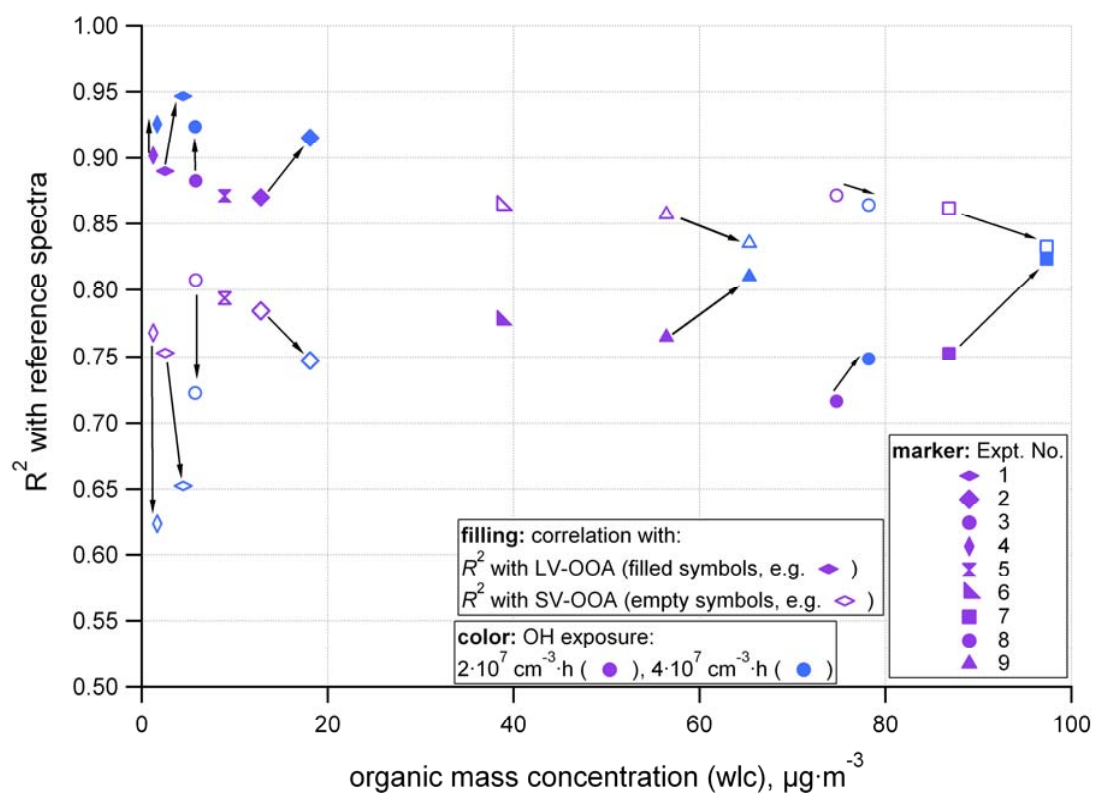

Fig. 4. Squares of the Pearson correlation coefficients, $R^{2}$, of measured mass spectra in comparison with LV-OOA (filled symbols) and SVOOA (empty symbols) reference spectra as a function of the organic mass concentration (wlc). The color code represents the $\mathrm{OH}$ exposure at the midpoint of a 30-min mass spectral average. The corresponding mass spectra are shown in Fig. S10 in the Supplement.

Table 4. The $\mathrm{OH}$ exposure required to increase the $\mathrm{O}: \mathrm{C}$ ratio above 0.6 at the corresponding organic mass concentration org (wlc). For experiments that do not exceed the threshold of 0.6 , the $\mathrm{OH}$ exposures are extrapolated and the maximum measured org (wlc) is given, both indicated by the asterisk.

\begin{tabular}{crr}
\hline Expt. No. & $\begin{array}{r}\text { OH exposure } \\
{\left[\times 10^{7} \mathrm{~cm}^{-3} \mathrm{~h}\right]}\end{array}$ & $\begin{array}{r}\text { org (wlc) } \\
{\left[\mu \mathrm{g} \mathrm{m}^{-3}\right]}\end{array}$ \\
\hline 1 & 4.7 & 4.4 \\
2 & 7.0 & 18.1 \\
5 & $7.2^{*}$ & $9.2^{*}$ \\
7 & $9.7^{*}$ & $97.2^{*}$ \\
6 & $11.6^{*}$ & $42.1^{*}$ \\
9 & $12.5^{*}$ & $66.2^{*}$ \\
8 & $19.8^{*}$ & $78.3^{*}$ \\
3 & $23.7^{*}$ & $6.2^{*}$ \\
4 & $35.2^{*}$ & $1.8^{*}$ \\
\hline
\end{tabular}

function of wall-loss-corrected organic mass concentration. For this comparison, all organic mass spectra are converted to be consistent with the fragmentation table of Aiken et al. (2008). The mass spectra for each of the nine experiments were averaged for $30 \mathrm{~min}$ surrounding the $\mathrm{OH}$ exposures of $2 \times 10^{7} \mathrm{~cm}^{-3} \mathrm{~h}$ and $4 \times 10^{7} \mathrm{~cm}^{-3} \mathrm{~h}$, respectively (i.e., the selected exposure $\pm 15 \mathrm{~min})$. All organic $\mathrm{m} / \mathrm{z}$ calculated as a constant fraction of $m / z$, 44 in the fragmentation table (i.e., $m / z 16,17,18,19,20$ and 28) were excluded from the correlation test to avoid overweighting of these ions. The general trend for both exposures shows increased correlation with
LV-OOA and decreased correlation with SV-OOA for decreasing mass concentrations. For all mass concentrations, an increasing $R^{2}$ (LV-OOA) and a decreasing $R^{2}$ (SV-OOA) with increasing $\mathrm{OH}$ exposure is found. The dependence on mass concentration occurs for the partitioning-related reasons discussed above in conjunction with increased $\mathrm{O}: \mathrm{C}$ for low mass concentrations, while the dependence on $\mathrm{OH}$ exposure occurs because SOA spectra become more LV-OOAlike with photochemical age. For the high-concentration experiments, the difference between $R^{2}$ (SV-OOA) and $R^{2}$ (LV-OOA) is more pronounced for the lower $\mathrm{OH}$ exposure than for the higher $\mathrm{OH}$ exposure. Nevertheless, the lower $R^{2}$ (LV-OOA) of the high-concentration experiments compared to the low-concentration experiments even for the enhanced $\mathrm{OH}$ exposure suggest a substantial difference in the chemical composition as a function of the organic aerosol loading. The low-concentration experiments (organic mass $<20 \mu \mathrm{g} \mathrm{m}^{-3}$ in Fig. 4) correlate strongly with LV-OOA $\left(R^{2}>0.9\right)$ for an $\mathrm{OH}$ exposure of $4 \times 10^{7} \mathrm{~cm}^{-3} \mathrm{~h}$. This indicates that for low organic mass concentrations, SOA from smog chamber $\alpha$-pinene photooxidation yields LV-OOA-like mass spectra after a sufficient oxidation time. Also for higher $\mathrm{OH}$ exposures, the correlation to LV-OOA is very high $\left(R^{2}>0.89\right)$ for the low-concentration experiments, while the $R^{2}$ values with SV-OOA decrease dramatically (Fig. S9, Supplement).

\section{Conclusions}

A series of smog chamber experiments were conducted to identify driving factors responsible for the discrepancy 
between ambient and smog chamber aerosol degree of oxygenation, which in turn strongly affects aerosol volatility and hygroscopicity. In this study, the aerosol products from $\alpha$ pinene photooxidation are located on the right-hand side of the $f_{44}-f_{43}$-space bounding the range of PMF factors previously identified in ambient SOA (Ng et al., 2010). The O : C ratio, a proxy for the degree of oxygenation, is increasing with decreasing organic mass loadings. This has been shown in a comparison of nine smog chamber experiments where the $\mathrm{OH}$ exposure was estimated to isolate the effects of mass loading and photochemical age. Similar dependencies of $f_{44}$ on the precursor concentration have been shown previously for other compounds than $\alpha$-pinene, such as $\beta$-caryophyllene (Alfarra et al., 2012).

We conclude that low (near-ambient level) organic mass loadings are required in order to obtain oxygenation levels comparable to those of the low-volatility oxygenated organic aerosol (LV-OOA) PMF factors retrieved in numerous field campaigns. An $\mathrm{OH}$ exposure between 3 and $25 \times 10^{7} \mathrm{~cm}^{-3} \mathrm{~h}$ is needed to increase $\mathrm{O}: \mathrm{C}$ by 0.05 during aerosol aging. This study marks the first smog chamber production of LVOOA-like SOA from the atmospherically relevant precursor $\alpha$-pinene. For ozonolysis of $\alpha$-pinene, the degree of oxygenation falls in the range of SV-OOA even at low concentrations (Shilling et al., 2009; Ng et al., 2010). This is consistent with the hypothesis of Donahue et al. (2012) that further aging occurs with $\mathrm{OH}$ after/together with ozonolysis. A correlation test between measured SOA and reference LV-OOA (Ng et al., 2011a) aerosol mass spectra shows Pearson's $R^{2}$ values larger than $90 \%$ for a sufficient $\mathrm{OH}$ exposure in the chamber in low mass concentration experiments $\left(\sim 1.2-20 \mu \mathrm{g} \mathrm{m}^{-3}\right)$. We suggest that smog chamber studies must not only be performed at reasonable oxidant concentrations but also at near-ambient mass concentrations to accurately simulate the chemical properties, volatility and hygroscopicity of ambient aerosol.

\section{Supplementary material related to this article is available online at: http://www.atmos-chem-phys.net/13/ 6493/2013/acp-13-6493-2013-supplement.pdf.}

Acknowledgements. This work has been supported by the EU 7th Framework projects EUROCHAMP-2 and PEGASOS, as well as the Swiss National Science Foundation. We thank Rene Richter and Günther Wehrle for their technical support at the smog chamber, and in addition Imad El-Haddad, Stephen Platt and Robert Wolf for discussions and their support during the experiments.

Edited by: J. Thornton

\section{References}

Aiken, A. C., DeCarlo, P. F., Kroll, J. H., Worsnop, D. R., Huffman, J. A., Docherty, K. S., Ulbrich, I. M., Mohr, C., Kimmel, J. R., Sueper, D., Sun, Y., Zhang, Q., Trimborn, A., Northway, M., Ziemann, P. J., Canagaratna, M. R., Onasch, T. B., Alfarra, M. R., Prevot, A. S. H., Dommen, J., Duplissy, J., Metzger, A., Baltensperger, U., and Jimenez, J. L.: O/C and OM/OC ratios of primary, secondary, and ambient organic aerosols with high-resolution time-of-flight aerosol mass spectrometry, Environ. Sci. Technol., 42, 4478-4485, 2008.

Alfarra, M. R., Hamilton, J. F., Wyche, K. P., Good, N., Ward, M. W., Carr, T., Barley, M. H., Monks, P. S., Jenkin, M. E., Lewis, A. C., and McFiggans, G. B.: The effect of photochemical ageing and initial precursor concentration on the composition and hygroscopic properties of $\beta$-caryophyllene secondary organic aerosol, Atmos. Chem. Phys., 12, 6417-6436, doi:10.5194/acp12-6417-2012, 2012.

Allan, J. D., Delia, A. E., Coe, H., Bower, K. N., Alfarra, M. R., Jimenez, J. L., Middlebrook, A. M., Drewnick, F., Onasch, T. B., Canagaratna, M. R., Jayne, J. T., and Worsnop, D. R.: A generalised method for the extraction of chemically resolved mass spectra from Aerodyne aerosol mass spectrometer data, J. Aerosol Sci., 35, 909-922, 2004.

Bahreini, R., Keywood, M. D., Ng, N. L., Varutbangkul, V., Gao, S., Flagan, R. C., Seinfeld, J. H., Worsnop, D. R., and Jimenez, J. L.: Measurements of secondary organic aerosol from oxidation of cycloalkenes, terpenes, and m-xylene using an Aerodyne aerosol mass spectrometer, Environ. Sci. Technol., 39, 5674-5688, 2005.

Baltensperger, U., Kalberer, M., Dommen, J., Paulsen, D., Alfarra, M. R., Coe, H., Fisseha, R., Gascho, A., Gysel, M., Nyeki, S., Sax, M., Steinbacher, M., Prevot, A. S. H., Sjogren, S., Weingartner, E., and Zenobi, R.: Secondary organic aerosols from anthropogenic and biogenic precursors, Faraday Discuss., 130, 265-278, 2005.

Barmet, P., Dommen, J., DeCarlo, P. F., Tritscher, T., Praplan, A. P., Platt, S. M., Prévôt, A. S. H., Donahue, N. M., and Baltensperger, U.: $\mathrm{OH}$ clock determination by proton transfer reaction mass spectrometry at an environmental chamber, Atmos. Meas. Tech., 5, 647-656, doi:10.5194/amt-5-647-2012, 2012.

Canonaco, F., Crippa, M., Slowik, J. G., Baltensperger, U., and Prévôt, A. S. H.: A newly developed interface for analyzing generalized Multilinear engine (ME-2) results: Application on aerosol mass spectrometer data, Atmos. Meas. Tech. Discuss., in preparation, 2013.

Chhabra, P. S., Ng, N. L., Canagaratna, M. R., Corrigan, A. L., Russell, L. M., Worsnop, D. R., Flagan, R. C., and Seinfeld, J. H.: Elemental composition and oxidation of chamber organic aerosol, Atmos. Chem. Phys., 11, 8827-8845, doi:10.5194/acp-11-88272011, 2011.

DeCarlo, P. F., Kimmel, J. R., Trimborn, A., Northway, M. J., Jayne, J. T., Aiken, A. C., Gonin, M., Fuhrer, K., Horvath, T., Docherty, K. S., Worsnop, D. R., and Jimenez, J. L.: Field-deployable, high-resolution, time-of-flight aerosol mass spectrometer, Anal. Chem., 78, 8281-8289, 2006.

DeCarlo, P. F., Ulbrich, I. M., Crounse, J., de Foy, B., Dunlea, E. J., Aiken, A. C., Knapp, D., Weinheimer, A. J., Campos, T., Wennberg, P. O., and Jimenez, J. L.: Investigation of the sources and processing of organic aerosol over the Central Mexican Plateau from aircraft measurements during MILAGRO, Atmos. 
Chem. Phys., 10, 5257-5280, doi:10.5194/acp-10-5257-2010, 2010.

Donahue, N. M., Robinson, A. L., Stanier, C. O., and Pandis, S. N.: Coupled partitioning, dilution, and chemical aging of semivolatile organics, Environ. Sci. Technol., 40, 2635-2643, 2006.

Donahue, N. M., Henry, K. M., Mentel, T. F., Kiendler-Scharr, A., Spindler, C., Bohn, B., Brauers, T., Dorn, H. P., Fuchs, H., Tillmann, R., Wahner, A., Saathoff, H., Naumann, K.-H., Möhler, O., Leisner, T., Müller, L., Reinnig, M.-C., Hoffmann, T., Salo, K., Hallquist, M., Frosch, M., Bilde, M., Tritscher, T., Barmet, P., Praplan, A. P., DeCarlo, P. F., Dommen, J., Prévôt, A. S. $\mathrm{H}$., and Baltensperger, U.: Aging of biogenic secondary organic aerosol via gas-phase $\mathrm{OH}$ radical reactions, P. Natl. Acad. Sci., 109, 13503-13508, doi:10.1073/pnas.1115186109, 2012.

Duplissy, J., Gysel, M., Alfarra, M. R., Dommen, J., Metzger, A., Prevot, A. S. H., Weingartner, E., Laaksonen, A., Raatikainen, T., Good, N., Turner, S. F., McFiggans, G., and Baltensperger, U.: Cloud forming potential of secondary organic aerosol under near atmospheric conditions, Geophys. Res. Lett., 35, L03818, doi:10.1029/2007GL031075, 2008.

Duplissy, J., DeCarlo, P. F., Dommen, J., Alfarra, M. R., Metzger, A., Barmpadimos, I., Prevot, A. S. H., Weingartner, E., Tritscher, T., Gysel, M., Aiken, A. C., Jimenez, J. L., Canagaratna, M. R., Worsnop, D. R., Collins, D. R., Tomlinson, J., and Baltensperger, U.: Relating hygroscopicity and composition of organic aerosol particulate matter, Atmos. Chem. Phys., 11, 11551165, doi:10.5194/acp-11-1155-2011, 2011.

Dusanter, S., Vimal, D., Stevens, P. S., Volkamer, R., and Molina, L. T.: Measurements of $\mathrm{OH}$ and $\mathrm{HO}_{2}$ concentrations during the MCMA-2006 field campaign - Part 1: Deployment of the Indiana University laser-induced fluorescence instrument, Atmos. Chem. Phys., 9, 1665-1685, doi:10.5194/acp-9-1665-2009, 2009.

El Haddad, I., D’Anna, B., Temime-Roussel, B., Nicolas, M., Boreave, A., Favez, O., Voisin, D., Sciare, J., George, C., Jaffrezo, J.-L., Wortham, H., and Marchand, N.: On the chemical nature of the oxygenated organic aerosol: implication in the formation and aging of $\alpha$-pinene SOA in a Mediterranean environment, Marseille, Atmos. Chem. Phys. Discuss., 12, 1976919797, doi:10.5194/acpd-12-19769-2012, 2012.

Heald, C. L., Kroll, J. H., Jimenez, J. L., Docherty, K. S., DeCarlo, P. F., Aiken, A. C., Chen, Q., Martin, S. T., Farmer, D. K., and Artaxo, P.: A simplified description of the evolution of organic aerosol composition in the atmosphere, Geophys. Res. Lett., 37, L08803, doi:10.1029/2010GL042737, 2010.

Heringa, M. F., DeCarlo, P. F., Chirico, R., Tritscher, T., Dommen, J., Weingartner, E., Richter, R., Wehrle, G., Prévôt, A. S. H., and Baltensperger, U.: Investigations of primary and secondary particulate matter of different wood combustion appliances with a high-resolution time-of-flight aerosol mass spectrometer, Atmos. Chem. Phys., 11, 5945-5957, doi:10.5194/acp-11-59452011, 2011.

Hodzic, A., Jimenez, J. L., Madronich, S., Canagaratna, M. R., DeCarlo, P. F., Kleinman, L., and Fast, J.: Modeling organic aerosols in a megacity: potential contribution of semi-volatile and intermediate volatility primary organic compounds to secondary organic aerosol formation, Atmos. Chem. Phys., 10, 5491-5514, doi:10.5194/acp-10-5491-2010, 2010.
Huffman, J. A., Docherty, K. S., Mohr, C., Cubison, M. J., Ulbrich, I. M., Ziemann, P. J., Onasch, T. B., and Jimenez, J. L.: Chemically-resolved volatility measurements of organic aerosol from different sources, Environ. Sci. Technol., 43, 5351-5357, 2009.

Jimenez, J. L., Canagaratna, M. R., Donahue, N. M., Prevot, A. S. H., Zhang, Q., Kroll, J. H., DeCarlo, P. F., Allan, J. D., Coe, H., Ng, N. L., Aiken, A. C., Docherty, K. S., Ulbrich, I. M., Grieshop, A. P., Robinson, A. L., Duplissy, J., Smith, J. D., Wilson, K. R., Lanz, V. A., Hueglin, C., Sun, Y. L., Tian, J., Laaksonen, A., Raatikainen, T., Rautiainen, J., Vaattovaara, P., Ehn, M., Kulmala, M., Tomlinson, J. M., Collins, D. R., Cubison, M. J., E, Dunlea, J., Huffman, J. A., Onasch, T. B., Alfarra, M. R., Williams, P. I., Bower, K., Kondo, Y., Schneider, J., Drewnick, F., Borrmann, S., Weimer, S., Demerjian, K., Salcedo, D., Cottrell, L., Griffin, R., Takami, A., Miyoshi, T., Hatakeyama, S., Shimono, A., Sun, J. Y., Zhang, Y. M., Dzepina, K., Kimmel, J. R., Sueper, D., Jayne, J. T., Herndon, S. C., Trimborn, A. M., Williams, L. R., Wood, E. C., Middlebrook, A. M., Kolb, C. E., Baltensperger, U., and Worsnop, D. R.: Evolution of organic aerosols in the atmosphere, Science, 326, 1525-1529, doi:10.1126/science.1180353, 2009.

Kang, E., Root, M. J., Toohey, D. W., and Brune, W. H.: Introducing the concept of Potential Aerosol Mass (PAM), Atmos. Chem. Phys., 7, 5727-5744, doi:10.5194/acp-7-5727-2007, 2007.

Kang, E., Toohey, D. W., and Brune, W. H.: Dependence of SOA oxidation on organic aerosol mass concentration and $\mathrm{OH}$ exposure: experimental PAM chamber studies, Atmos. Chem. Phys., 11, 1837-1852, doi:10.5194/acp-11-1837-2011, 2011.

Lambe, A. T., Onasch, T. B., Massoli, P., Croasdale, D. R., Wright, J. P., Ahern, A. T., Williams, L. R., Worsnop, D. R., Brune, W. H., and Davidovits, P.: Laboratory studies of the chemical composition and cloud condensation nuclei (CCN) activity of secondary organic aerosol (SOA) and oxidized primary organic aerosol (OPOA), Atmos. Chem. Phys., 11, 8913-8928, doi:10.5194/acp11-8913-2011, 2011.

Lanz, V. A., Prévôt, A. S. H., Alfarra, M. R., Weimer, S., Mohr, C., DeCarlo, P. F., Gianini, M. F. D., Hueglin, C., Schneider, J., Favez, O., D’Anna, B., George, C., and Baltensperger, U.: Characterization of aerosol chemical composition with aerosol mass spectrometry in Central Europe: an overview, Atmos. Chem. Phys., 10, 10453-10471, doi:10.5194/acp-10-10453-2010, 2010.

Massoli, P., Lambe, A. T., Ahern, A. T., Williams, L. R., Ehn, M., Mikkilä, J., Canagaratna, M. R., Brune, W. H., Onasch, T. B., Jayne, J. T., Petäjä, T., Kulmala, M., Laaksonen, A., Kolb, C. E., Davidovits, P., and Worsnop, D. R.: Relationship between aerosol oxidation level and hygroscopic properties of laboratory generated secondary organic aerosol (SOA) particles, Geophys. Res. Lett., 37, L24801, doi:10.1029/2010GL045258, 2010.

Metzger, A., Dommen, J., Gaeggeler, K., Duplissy, J., Prevot, A. S. H., Kleffmann, J., Elshorbany, Y., Wisthaler, A., and Baltensperger, U.: Evaluation of 1,3,5 trimethylbenzene degradation in the detailed tropospheric chemistry mechanism, MCMv3.1, using environmental chamber data, Atmos. Chem. Phys., 8, 6453-6468, doi:10.5194/acp-8-6453-2008, 2008.

Metzger, A., Verheggen, B., Dommen, J., Duplissy, J., Prevot, A. S. H., Weingartner, E., Riipinen, I., Kulmala, M., Spracklen, D. V., Carslaw, K. S., and Baltensperger, U.: Evidence for the role of organics in aerosol particle formation under 
atmospheric conditions, P. Natl. Acad. Sci., 107, 6646-6651, doi:10.1073/pnas.0911330107, 2010.

Ng, N. L., Canagaratna, M. R., Zhang, Q., Jimenez, J. L., Tian, J., Ulbrich, I. M., Kroll, J. H., Docherty, K. S., Chhabra, P. S., Bahreini, R., Murphy, S. M., Seinfeld, J. H., Hildebrandt, L., Donahue, N. M., DeCarlo, P. F., Lanz, V. A., Prévôt, A. S. H., Dinar, E., Rudich, Y., and Worsnop, D. R.: Organic aerosol components observed in Northern Hemispheric datasets from Aerosol Mass Spectrometry, Atmos. Chem. Phys., 10, 46254641, doi:10.5194/acp-10-4625-2010, 2010.

Ng, N. L., Canagaratna, M. R., Jimenez, J. L., Chhabra, P. S., Seinfeld, J. H., and Worsnop, D. R.: Changes in organic aerosol composition with aging inferred from aerosol mass spectra, Atmos. Chem. Phys., 11, 6465-6474, doi:10.5194/acp-11-64652011, 2011a.

Ng, N. L., Canagaratna, M. R., Jimenez, J. L., Zhang, Q., Ulbrich, I. M., and Worsnop, D. R.: Real-time methods for estimating organic component mass concentrations from aerosol mass spectrometer data, Environ. Sci. Technol., 45, 910-916, $2011 \mathrm{~b}$.

Paatero, P.: The multilinear engine - A table-driven, least squares program for solving multilinear problems, including the n-way parallel factor analysis model, J. Comput. Graph. Stat., 8, 854888, doi:10.2307/1390831, 1999.

Paulsen, D., Dommen, J., Kalberer, M., Prévôt, A. S. H., Richter, R., Sax, M., Steinbacher, M., Weingartner, E., and Baltensperger, U.: Secondary organic aerosol formation by irradiation of 1,3,5trimethylbenzene- $\mathrm{NO}_{\mathrm{x}}-\mathrm{H}_{2} \mathrm{O}$ in a new reaction chamber for atmospheric chemistry and physics, Environ. Sci. Technol., 39, 2668-2678, 2005.
Robinson, A. L., Donahue, N. M., Shrivastava, M. K., Weitkamp, E. A., Sage, A. M., Grieshop, A. P., Lane, T. E., Pierce, J. R., and Pandis, S. N.: Rethinking organic aerosols: Semivolatile emissions and photochemical aging, Science, 315, 1259-1262, 2007.

Shilling, J. E., Chen, Q., King, S. M., Rosenoern, T., Kroll, J. H., Worsnop, D. R., DeCarlo, P. F., Aiken, A. C., Sueper, D., Jimenez, J. L., and Martin, S. T.: Loading-dependent elemental composition of $\alpha$-pinene SOA particles, Atmos. Chem. Phys., 9, 771-782, doi:10.5194/acp-9-771-2009, 2009.

Slowik, J. G., Wong, J. P. S., and Abbatt, J. P. D.: Real-time, controlled $\mathrm{OH}$-initiated oxidation of biogenic secondary organic aerosol, Atmos. Chem. Phys., 12, 9775-9790, doi:10.5194/acp12-9775-2012, 2012.

Taira, M. and Kanda, Y.: Continuous generation system for lowconcentration gaseous nitrous acid, Anal. Chem., 62, 630-633, 1990.

Ulbrich, I. M., Canagaratna, M. R., Zhang, Q., Worsnop, D. R., and Jimenez, J. L.: Interpretation of organic components from Positive Matrix Factorization of aerosol mass spectrometric data, Atmos. Chem. Phys., 9, 2891-2918, doi:10.5194/acp-9-2891-2009, 2009.

Van Krevelen, D. W.: Graphical-statistical method for the study of structure and reaction processes of coal, Fuel, 24, 269-284, 1950.

Volkamer, R., Jimenez, J. L., San Martini, F., Dzepina, K., Zhang, Q., Salcedo, D., Molina, L. T., Worsnop, D. R., and Molina, M. J.: Secondary organic aerosol formation from anthropogenic air pollution: Rapid and higher than expected, Geophys. Res. Lett., 33, L17811, doi:10.1029/2006GL026899, 2006. 